\title{
Mercury, selenium and fish oils in marine food webs and implications for human health - CORRIGENDUM
}

MATTHEW O. GRIBBLE, ROXANNE KARIMI, BETH J. FEINGOLD, JENNIFER F. NYLAND, TODD M. O'HARA, MICHAIL I. GLADYSHEV AND CELIA Y. CHEN

DOI:10.1017/Soo25315415001356, First published online by Cambridge University Press, 8 September 2015.

There was an error in the citations of Table 2, in which the references for the Sockeye salmon taxon were identified as Gladyshev et al., both $2012 \mathrm{a}$ and $2012 \mathrm{~b}$. However, the correct reference is only $2012 \mathrm{~b}$.

The authors apologise for this error.

REFERENCE

Matthew O. Gribble, Roxanne Karimi, Beth J. Feingold, Jennifer F. Nyland, Todd M. O'Hara, Michail I. Gladyshev and Celia Y. Chen (2016) Mercury, selenium and fish oils in marine food webs and implications for human health. Journal of the Marine Biological Association of the United Kingdom 96, 43-59. doi: 10.1017/Soo25315415001356. 